\title{
The effect of turning frequency on methane generation during composting of anaerobic digestion material
}

\author{
Anh hương của sụ đảo trộn đến quá trình sinh khí mê tan trong đống ủ phân \\ compost của chất thái tù̀ hầm ủ biogas \\ Research article
}

Nguyen Thanh Phong ${ }^{*}$; Carsten Cuhls ${ }^{2}$

${ }^{1}$ Faculty of Science and Technology, Hoa Sen University, 8 Nguyen Van Trang, District 1, HCM City, Vietnam,

${ }^{2}$ Faculty of Water and Waste Management, Magdeburg University, Breitscheidstr. 2, 39114, Magdeburg, Germany

\begin{abstract}
Methane $\left(\mathrm{CH}_{4}\right)$ is included in the direct greenhouse gases listed in the Kyoto protocol. The composting of anaerobic digestion (henceforth $\mathrm{AD}$ ) material is a source of $\mathrm{CH}_{4} \cdot \mathrm{CH}_{4}$ is the major contributor to overall $\mathrm{CO}_{2}$ emissions. Therefore, it is important to know the formation of this gas from different stages and substrates of the composting process. This study investigated $\mathrm{CH}_{4}, \mathrm{CO}_{2}$ and $\mathrm{O}_{2}$ profiles in two open-windrows in composting plants treating $\mathrm{AD}$ material. One composting windrow was turned one a week; whereas another was turned twice a week using a special windrow turner. To assess the gaseous formation in the composting windrows, $\mathrm{CH}_{4}, \mathrm{CO}_{2}$ and $\mathrm{O}_{2}$ volume concentrations were measured at different depths. Active aeration has been considered as a method to reduce $\mathrm{CH}_{4}$ generation during composting. However, our results showed that frequent turned windrow generated more $\mathrm{CH}_{4}$ than less turned windrow. The highest $\mathrm{CH}_{4}$ concentrations were found at a depth of $1 \mathrm{~m}$, and were $45 \%$ and $37 \%$ for 2 times a week turned windrow and 1 time a week turned windrow respectively. Gas concentrations of $\mathrm{CH}_{4}, \mathrm{O}_{2}$ and $\mathrm{CO}_{2}$ in both windrows differed. Concentrations of $\mathrm{CO}_{2}$ and $\mathrm{CH}_{4}$ increased with depth, whereas concentration of $\mathrm{O}_{2}$ decreased from the surface to the lowest point. The $\mathrm{O}_{2}$ and $\mathrm{CO}_{2}$ are important factors in determining whether the windrows are anaerobic or aerobic.
\end{abstract}

Khí mê tan $\left(\mathrm{CH}_{4}\right)$ là một trong nhũng khí nhà kính được liệt kê trong nghị định thu Kyoto. Quá trình ủ phân compost tù các chất thải của hầm ủ biogas là nguồn phát sinh loại khí này. Khí mê tan đóng góp chủ yếu trong tổng luợng khi nhà kính phát thải vào khi quyển. Do đó, những hiểu biết về quá trình hình thành loại khi này trong các giai đoạn khác nhau của quá trình ủ phân compost tù chất thải hầm ủ biogas là rất quan trọng. Nghiên cứu này tìm hiểu sự phát thải khí $\mathrm{CH}_{4}$, $\mathrm{CO}_{2}$ và $\mathrm{O}_{2}$ trong 2 luống ủ ngoài trò̀i tại các nhà máy xủ lý rác thải hũu co bằng phuong pháp ky. khí. Luống ủ 1 được đảo trộn một lần một tuần trong khi luống ủ số 2 được đảo trộn 2 lần 1 tuần. Để đo đạc luợng khí phát thải tù các luống ủ phân compost, nồng độ các khí $\mathrm{CH}_{4}, \mathrm{CO}_{2}$ và $\mathrm{O}_{2}$ được đo ở các độ sâu khác nhau. Việc cung cấp khí oxy được coi nhu là một biện pháp để làm giảm sụ hìn thành khi mê tan. Tuy nhiên, kết quả đo đạc của chúng tôi chưng minh rằng việc đảo trộn thưòng xuyên phát thải nhiều khí mê tan hơn it đảo trộn. Nồng độ khí mê tan cao nhất $45 \%$ và $37 \%$ đo được ở khoảng cách $1 \mathrm{~m}$ tù bề mặt đối với luống ủ đảo trộn hai lần và một lần. Nồng độ các khi $\mathrm{CH}_{4}, \mathrm{CO}_{2}$ và $\mathrm{O}_{2}$ khác nhau ở hai luống trong thi nghiệm. Nồng độ khi $\mathrm{CH}_{4}$ và $\mathrm{CO}_{2}$ tăng theo độ sâu, trong khi $\mathrm{O}_{2}$ giảm theo độ sâu. Nồng độ khi $\mathrm{CO}_{2}$ và $\mathrm{O}_{2}$ đóng vai trò quyết định luống ủ được cung cấp đủ oxy cho quá trình phân hủy hiếu khí hay không.

Keywords: greenhouse gas, emissions, composting, windrows, organic waste, methane 


\section{Introduction}

Anaerobic digestion (AD) material is treated either by active aeration composting or by a combination of active aeration and open composting windrow (Mata-Alvarez et al., 2000). Aeration is an important parameter in controlling the composting process (de Guardia et al., 2008; Maeda et al., 2010). Microbes are supplied oxygen for hydrocarbon degradation and elevate the compost temperature to the thermophilic range. Aeration is a key element in controlling the temperature regime and thus, the performance of any composting operation (Beck-Friis et al., 2000; Thompson et al., 2004; Fukumoto et al., 2003). Under aerobic conditions, microbes can rapidly degrade the available hydrocarbons releasing large amounts of energy to elevate the compost temperature to the thermophilic range.

It is known that increasing the oxygen supply will reduce the methane formation and emissions (Möller \& Sommer, 2000). During the composting process, the production of methane is strongly dependent on process management. Methane is a main product of anaerobic methanogenesis, while carbon dioxide is a main product of both aerobic and anaerobic processes (Hellebrand, 1998). Hence, substrate quality and quantity, its aeration rate, and the duration of composting influence these gas productions. (Beck-Friis et al., 2000; He et al., 2000; Möller \& Sommer, 2000; Hao et al., 2001; Clemens \& Cuhls, 2003; Fukumoto et al., 2003; Thompson et al., 2004). Only a few studies regarding direct gaseous formation in the anaerobic digestion material composting are available.

The aim of this research is to examine the concentration of $\mathrm{CH}_{4}, \mathrm{CO}_{2}$ and $\mathrm{O}_{2}$ in two composting windrows from AD material. Furthermore, temperature, moisture content and oDM were measured during the study. Investigations were undertaken at a mechanical biological treatment plant in Germany treating biowaste and AD material.

\section{Materials and methods}

\subsection{Site description and compost system}

The primary objective was to measure and analyze the concentrations of $\mathrm{CH}_{4}, \mathrm{CO}_{2}, \mathrm{~N}_{2} \mathrm{O}$ and $\mathrm{O}_{2}$ in two different windrows using different composting management. One composting windrow was turned one a week; whereas another was turned twice a week using a special windrow turner. The composting process was limited to 10 weeks. The study was conducted at a mechanical biological treatment (MBT) plant in Germany. All of the incoming biowaste enters the continuous anaerobic digestion system. The MBT plant consists of one wet fermenter. The biowaste is first shredded and pressed to dry and wet fractions. The wet fraction is then pumped into a vertical fermenter, where temperature is maintained at thermophilic conditions $\left(55^{\circ} \mathrm{C}\right)$. The hydraulic retention time is about 20 days. Feed is added to the fermenter at regular intervals. The digestate is separated into a solid and a liquid fraction by a decanter. The liquid fraction is recirculated into the process. The excess liquid is transport- ed to farms and used as liquid fertilizer. The solid fraction is mixed with dry fraction and aerated in 14 days in an intensive composting tunnel without turning. Then, the material is piled up in small triangular windrows placed on a floor and is composted for another 35 days.

In the study, the gases $\left(\mathrm{CH}_{4}, \mathrm{CO}_{2}\right.$ and $\left.\mathrm{O}_{2}\right)$ were studied in the small triangular windrow. To conduct the research, the material aerated in the composting tunnel was arranged in triangular windrows, each $25 \mathrm{~m}$ long, $6 \mathrm{~m}$ wide (on the ground) and $2 \mathrm{~m}$ high. The material was placed on a concrete floor. The composting material was AD material (> $100 \mathrm{~mm}, 49 \% \mathrm{DM}$ and $23.7 \% \mathrm{oDM}$ ).

The greenhouse gas concentrations in each windrow were measured every week. In addition, composting material was sampled and analyzed DM and oDM in the laboratory. After 10 weeks, the composting material was sieved $(15 \mathrm{~mm})$ by a machine (Doppstadt-Sieb). The small fraction was collected for analyzing DM and oDM. In all, ten measurements were taken placed in the study.

\subsection{Pore gas measurements}

Gas concentrations in both windrows were analyzed. Three gradients were sampled in the windrow. At each sampling point, a gas probe was drilled into the windrow to a depth of $0.2,0.4,0.6,0.8$ and $1 \mathrm{~m}$. Gas from the pore space was sucked into an infrared analyzer by a pump to detect $\mathrm{CH}_{4}, \mathrm{CO}_{2}$ and $\mathrm{O}_{2}$. As a control, gas was sampled using $20 \mathrm{ml}$ evacuated headspace vials. These were subsequently analyzed for $\mathrm{CH}_{4}$ in the laboratory at the University of Bonn using Gas chromatography (GC) with Electron Capture Detector and Flame Ionization Detector (ECD/FID), (The Shimadzu Gas Chromatograph Mass Spectrometer GCMS-QP2010).

\subsection{Temperature and moisture content measurements}

The temperature was recorded every day. Six gradients were observed in the windrow. At each sampling point, a temperature probe was drilled into the windrow to a depth of 0.3 and $1 \mathrm{~m}$. The moisture content was determined by drying the samples at $105^{\circ} \mathrm{C}$ until the weight was unvarying. The percentage of moisture content was calculated in relation to the initial weight.

\section{Results and discussion}

\subsection{Trend of temperature and moisture con- tent}

High temperatures (Fig. 1A and B) characterized in both studied windrows. After 7 days, the temperatures were above $60^{\circ} \mathrm{C}$ and remained during 30 days. The difference in temperature regimes between two windrows was insignificant. The temperature at 0.3 and $1 \mathrm{~m}$ depth were similar over the first 25 days. From the day 25 onward, significant temperature differences $\left(\right.$ ca. $10^{\circ} \mathrm{C}$ ) occurred at depth $0.3 \mathrm{~m}$ and $1 \mathrm{~m}$. Figure 1 also documents that the temperature reached maximum temperature $75^{\circ} \mathrm{C}$ in both wind- 
rows in 26 days. After 35 days composting, a decrease in temperature without marked differences between windrow 1 and 2 was recorded.

At the start of the study, water content (WC) was nearly $60 \%$. WC decreased gradually to the value of $50 \%$ in both windrows. The WC of windrow 1 , which was turned 2 twice a week were rather higher than the windrow 2 turned 1 a week. During the study, the rainfall occurred; therefore, the windrow 1 was wetter due to the absorption of precipitation after turning. A higher moisture content leads to higher GHG emissions because it creates anaerobic conditions (Tamura \& Osada, 2006).
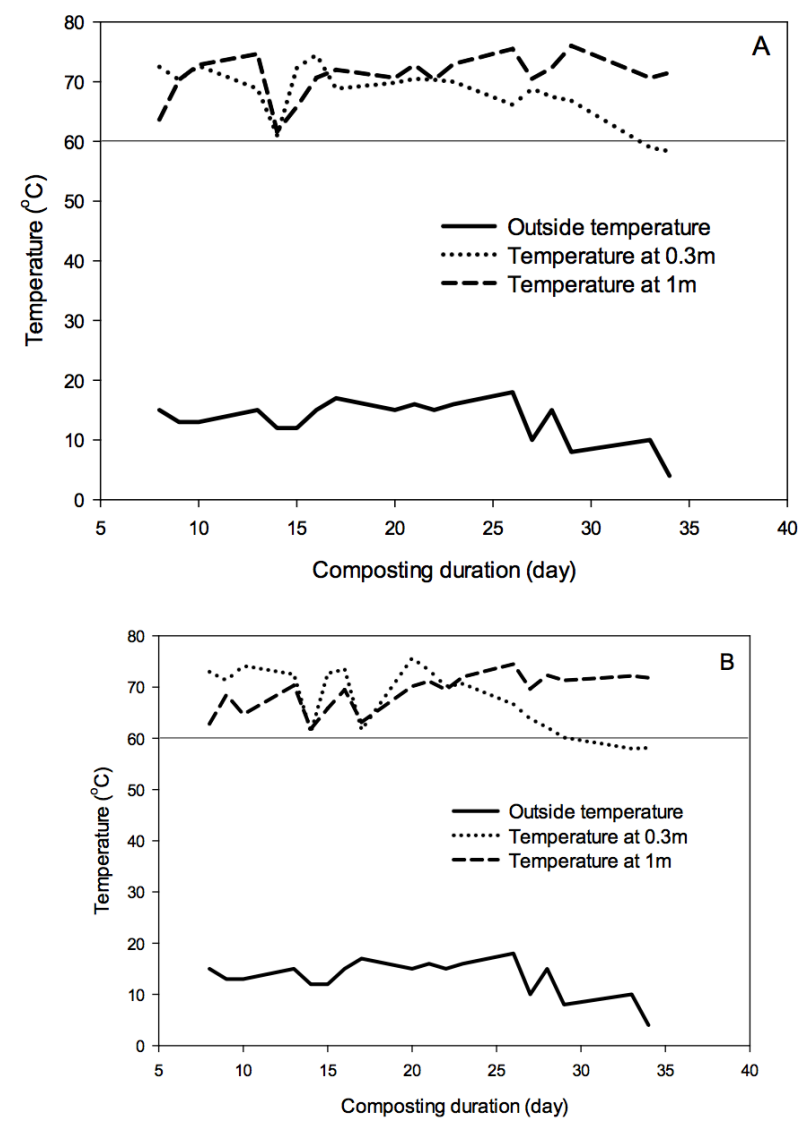

Figure 1: Temperature during the composting process. (A) Windrow 1 (turned twice a week). (B) Windrow 2 (turned 1 a week), measured a depth of $30 \mathrm{~cm}$ (dotted lines) and $1 \mathrm{~m}$ (dashed lines)

Dry organic matter (oDM) decreased lightly during the 35 day composting from initial values of $29 \%$ to $20 \%$ in the windrow 1 (Fig. 2). A significant difference in the oDM content $(9 \%)$ between the windrow 1 and 2 occurred at the day 35. Tendency, frequent turning reduced oDM due to water evaporation and $\mathrm{N}$ loss. This result was in line with results from previous studies demonstrating the influence of windrow turning on water evaporation and organic material degradation (Szanto et al., 2007; Ahn et al., 2011).

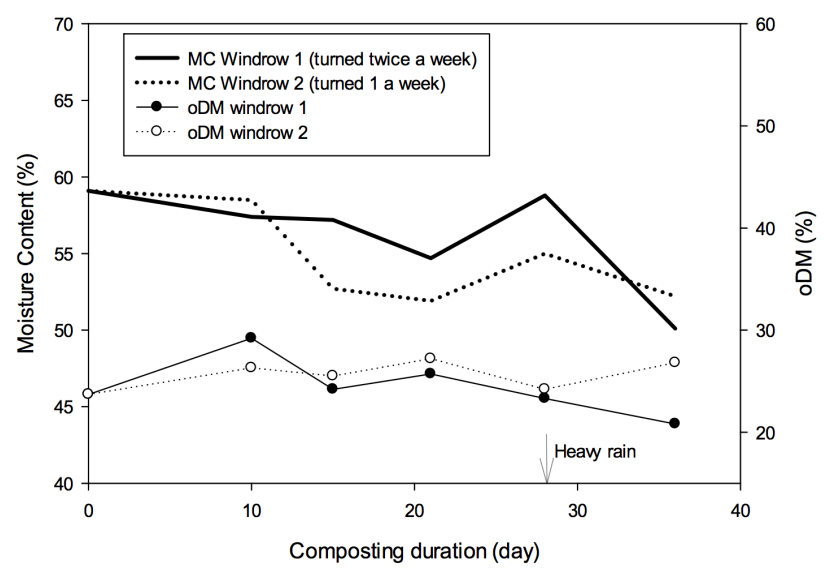

Figure 2: Moisture content and oDM during composting treatment

\subsection{Gas phase concentration in the compost- ing windrow}

$\mathrm{CH}_{4}$ concentration in pores of both windrows increased significantly from 0.2 to $1 \mathrm{~m}$ (Fig. 3). The highest $\mathrm{CH}_{4}$ concentrations were $35 \%$ for windrow 1 and $27 \%$ for windrow 2. The high concentration of $\mathrm{CH}_{4}$ found in the study was similar to those reported by (Beck-Friis et al., 2000; Georgaki et al., 2009; Ahn et al., 2011). The generation patterns of $\mathrm{CH}_{4}$ in the study resembled those reported by other works (Beck-Friis et al., 2000; Georgaki et al., 2009).

The maximum value of $\mathrm{CH}_{4}$ concentration appeared on the tenth day, reaching $35 \%$ and $27 \%$ for window 1 and 2 respectively. The high $\mathrm{CH}_{4}$ generation demonstrated the absence of oxygen and the involvement of anoxic/anaerobic micro-organisms (He et al., 2000). $\mathrm{CH}_{4}$ concentrations were high in both windrows during the first days and reduced significantly to the last day. Higher $\mathrm{CH}_{4}$ generation occurred in the windrow 1 compared to windrow 2. The higher $\mathrm{CH}_{4}$ generation in the 2 times turned windrow on the first days could be explained by the fact that $\mathrm{CH}_{4}$ was produced through degradation of organic substances and organic acids in anaerobic conditions (Fukumoto et al., 2003; Jiang et al., 2010). 
$\mathrm{CH}_{4}$-Concentration (\%)

$\mathrm{CH}_{4}$-Concentration (\%)
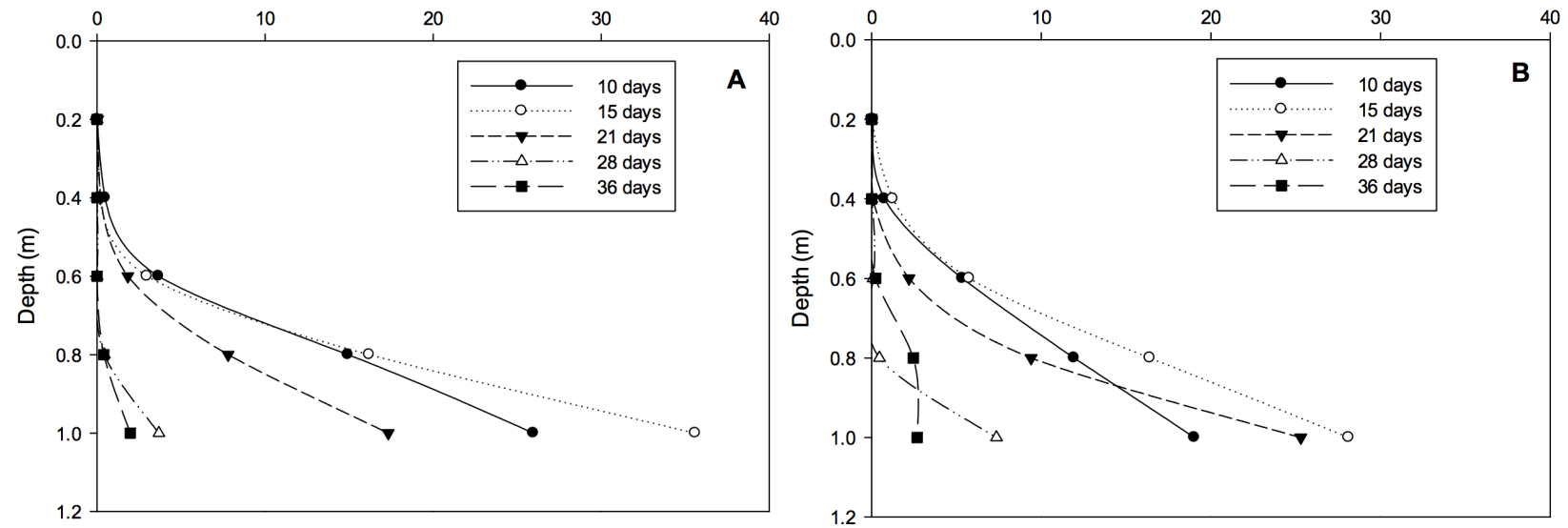

Figure 3: $\mathrm{CH}_{4}$ concentration in the windrows. (A) windrow 1 (turned twice a week). (B) windrow 2 (turned 1 a week), measured over the course of maturation of the composting the compost windrows

As can be seen in Fig. 4, $\mathrm{CO}_{2}$ decreased with depth. At $1 \mathrm{~m}$ depth, $\mathrm{CO}_{2}$ concentrations were $45 \%$ and $38 \%$ in the windrow 1 and 2 respectively. The $\mathrm{CO}_{2}$ generation more than $30 \%$ in both two windrows from day 10 to day 15 . There were significant differences in $\mathrm{CO}_{2}$ generation between the windrow 1 and 2 from the first 21 days during the composting. Gas generations were high in the early stage of composting. Higher $\mathrm{CO}_{2}$ generation occurred in the windrow 1 compared to windrow 2. $\mathrm{CO}_{2}$ concentrations were decreased from $45 \%$ to $15 \%$ and from $38 \%$ to $20 \%$ in the windrow 1 and 2 respectively at the end of the composting.
The generation rates mainly depended on the turning frequency, and as the frequent turning was increased, the level of $\mathrm{CO}_{2}$ generation increased.

The $\mathrm{O}_{2}$ concentration decreased significantly from 0.2 to $1 \mathrm{~m}$ in both windrows (Fig. 5). The decrease of $\mathrm{O}_{2}$ from the surface to the lowest point was due to biological activity that consumed $\mathrm{O}_{2}$. Our results are also consistent with the conclusions of (Xu et al., 2007). The highest $\mathrm{O}_{2}$ concentration was at $0.2 \mathrm{~m}$ and the lowest at $1 \mathrm{~m}$.
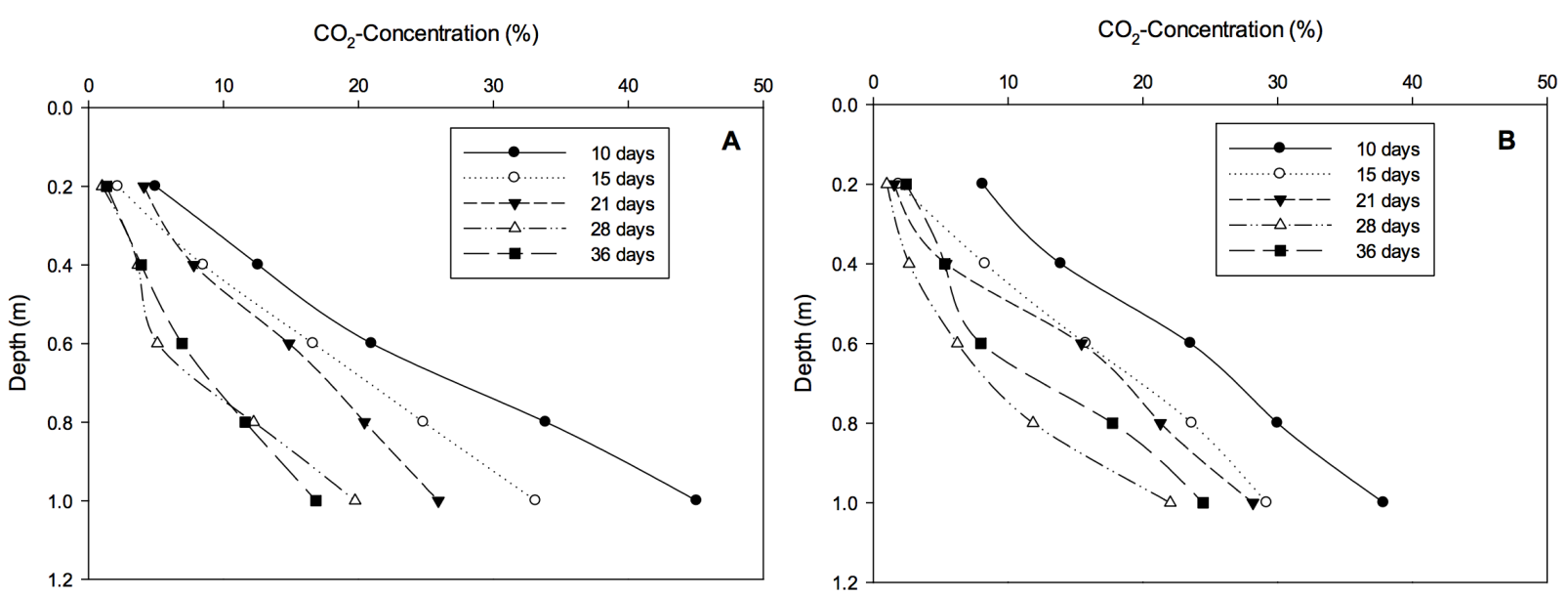

Figure 4: $\mathrm{CO}_{2}$ concentration in the windrows. (A) windrow 1 (turned twice a week). (B) windrow 2 (turned 1 a week), measured over the course of maturation of the composting the compost windrows 

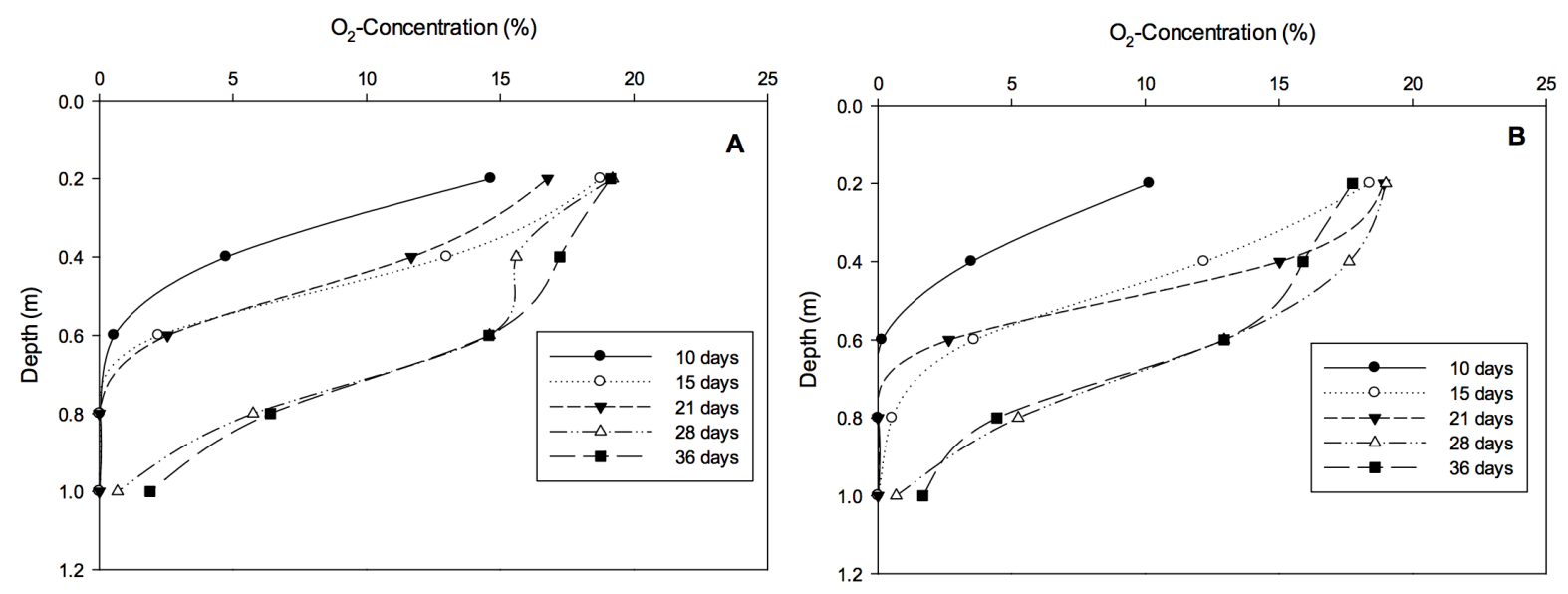

Figure 5: $\mathrm{O}_{2}$ concentration in the windrows. (A) windrow 1 (turned twice a week). (B) windrow 2 (turned 1 a week), measured over the course of maturation of the composting the compost windrows

\subsection{Correlation of $\mathrm{O}_{2}$ and $\mathrm{CO}_{2}$ in the com- posting windrows}

In the windrows, the $\mathrm{O}_{2}$ and $\mathrm{CO}_{2}$ concentrations $(\%)$ were negatively correlated (Fig. 6). An increase in $\mathrm{CO}_{2}$ concentration led to a decrease in $\mathrm{O}_{2}$ concentration and vice versa. This result is in line with (Sommer et al., 2004; Thompson et al., 2004 and Park et al., 2011). When $\mathrm{CO}_{2}$ concentrations were above $20 \%, \mathrm{O}_{2}$ concentrations dropped to $0 \%$. High $\mathrm{O}_{2}$ and $\mathrm{CO}_{2}$ concentrations in the composting windrow are evidence of aerobic decomposition (Hao et al., 2001). The decomposition of organic material with the presence of $\mathrm{O}_{2}$ produces $\mathrm{CO}_{2}$ and $\mathrm{H}_{2} \mathrm{O}$, whereas the decomposition under anaerobic conditions produces $\mathrm{CH}_{4}$ and $\mathrm{CO}_{2}$. Although, concentration of $\mathrm{O}_{2}$ was nil, the degradation processes in windrow still seemed to be aerobic due to high concentrations of $\mathrm{CO}_{2}$ (up to 20\%). $\mathrm{O}_{2}$ enter at the sides of the windrow, but only $\mathrm{O}_{2}$ is consumed and transformed into $\mathrm{CO}_{2}$ via respiration. Theoretically, a windrow with a $\mathrm{CO}_{2}$ concentration of $20 \%$ could be still aerobic. Low concentration of $\mathrm{O}_{2}$ but high concentration of $\mathrm{CO}_{2}$ indicated that a chimney effect had developed in the windrow due to the convective transportation of gases.

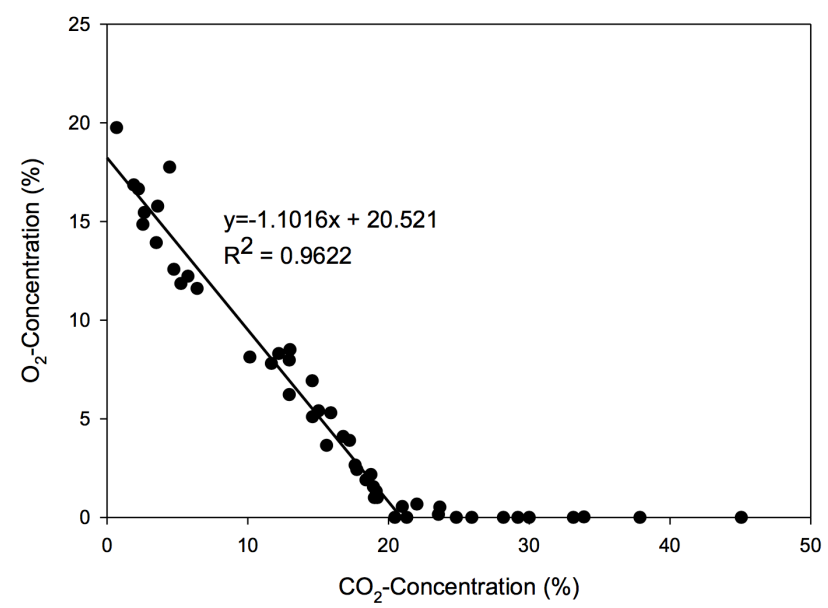

Figure 6: Concentration of $\mathrm{O}_{2}$ and $\mathrm{CO}_{2}$ in windrows

\section{Conclusions}

The effects of turning frequency and moisture content on the generations of $\mathrm{CH}_{4}, \mathrm{CO}_{2}$ and $\mathrm{O}_{2}$ during composting of anaerobic digestion material were investigated in this study. The results of this investigation have shown that there were differences in the generation of gases from anaerobic digestion material which are dependent on one or two times turning frequency a week. Methane was produced more in the frequent turned windrow during the first days.

$\mathrm{CH}_{4}, \mathrm{CO}_{2}$ and $\mathrm{O}_{2}$ profiles in open-windrows differed. $\mathrm{CH}_{4}$ and $\mathrm{CO}_{2}$ concentrations in the windrow increased with depth; whereas, $\mathrm{O}_{2}$ decreased. $\mathrm{CH}_{4}$ was produced at high rate $(>15 \%)$ in the center of the windrows during the first 3 weeks. Production of $\mathrm{CH}_{4}$ was low at the surface layers (0.3 m depth) due to $\mathrm{O}_{2}$ availability. At $1 \mathrm{~m}$ depth, $\mathrm{CH}_{4}$ and $\mathrm{CO}_{2}$ were high at day 10 and decreased during the composting. Lower oxygen concentration caused higher methane generation. The moisture content and oDM reduced during the composting period, but not significantly.

Analyzing $\mathrm{O}_{2}$ concentration alone is not enough to determine whether the windrow is aerobic or anaerobic. When $\mathrm{O}_{2}$ and $\mathrm{CO}_{2}$ concentration were $0 \%$ and $20 \%$ respectively, it was still aerobic in the windrow $\left(\mathrm{CH}_{4}\right.$ concentration was $0 \%$ ).

\section{References}

[1] Ahn, H. K., W., M., J.W., W. \& S.L., K. 2011. Pile mixing increases greenhouse gas emissions during composting of dairy manure. Bioresource Technology, 102 2904-2909.

[2] Beck-Friis, B., Pell, M., Sonesson, U., Jönsson, H. \& Kirchmann, H. 2000. Formation and Emission of $\mathrm{N} 2 \mathrm{O}$ and $\mathrm{CH} 4$ from Compost Heaps of Organic Household Waster. Environmental Monitoring and Assessment, 62, 317-331.

[3] Clemens, J. \& Cuhls, C. 2003. Greenhouse gas emissions from mechanical and biological waste treatment of municipal waste. Environmental Tech- 
nology, 24, 745-754.

[4] de Guardia, A. d., Petiot, C., Rogeau, D. \& Druilhe, C. 2008. Influence of aeration rate on nitrogen dynamics during composting. Waste Management, 28, $575-587$.

[5] Fukumoto, Y., Osada, T., Hanajima, D. \& Haga, K. 2003. Patterns and quantities of $\mathrm{NH}_{3}, \mathrm{~N}_{2} \mathrm{O}$ and $\mathrm{CH}_{4}$ emissions during swine manure composting without forced aeration--effect of compost pile scale. Bioresource Technology, 89, 109-114.

[6] Georgaki, I., Tsamoukas, A., Sakkas, N., Ververidis, F., Trantas, E., Kyriacou, A., Lasaridi, K. E. \& Manios, T. 2009. The Role of Bulking Agent in Pile Methane and Carbon Dioxide Concentration during Wastewater Sludge Windrow Composting. Water Environment Research, 81, 5-12.

[7] Hao, X., Chang, C., Larney, F. J. \& Travis, G. R. 2001. Greenhouse Gas Emissions during Cattle Feedlot Manure Composting. J. Environ. Qual., 30, 376-386.

[8] He, Y., Inamori, Y., Mizuochi, M., Kong, H., Iwami, N. \& Sun, T. 2000. Measurements of $\mathrm{N}_{2} \mathrm{O}$ and $\mathrm{CH}_{4}$ from the aerated composting of food waste. Science of The Total Environment, 254, 65-74.

[9] Hellebrand, H. J. 1998. Emission of Nitrous Oxide and other Trace Gases during Composting of Grass and Green Waste. Journal of Agricultural Engineering Research, 69, 365-375.

[10] Jiang, T., Schuchardt, F., Li, G., Guo, R. \& Zhao, Y. 2010. Effect of $\mathrm{C} / \mathrm{N}$ ratio, aeration rate and moisture content on ammonia and greenhouse gas emission during the composting. Journal of Environmen- tal Sciences, 23, 1754-1760.

[11] Maeda, K., Morioka, R., Hanajima, D. \& Osada, T. 2010. The Impact of Using Mature Compost on Nitrous Oxide Emission and the Denitrifier Community in the Cattle Manure Composting Process. Microbial Ecology, 59, 25-36.

[12] Mata-Alvarez, J., Macé, S. \& Llabrés, P. 2000. Anaerobic digestion of organic solid wastes. An overview of research achievements and perspectives. Bioresource Technology, 74, 3-16.

[13] Möller, H. B. \& Sommer, S. G. 2000. Emission of greenhouse gases during composting of deep litter from pig production - effect of straw content. The Journal of Agricultural Science, 134, 327-335.

[14] Szanto, G. L., Hamelers, H. V. M., Rulkens, W. H. \& Veeken, A. H. M. 2007. $\mathrm{NH}_{3}, \mathrm{~N}_{2} \mathrm{O}$ and $\mathrm{CH}_{4}$ emissions during passively aerated composting of strawrich pig manure. Bioresource Technology, 98, 26592670 .

[15] Tamura, T. \& Osada, T. 2006. Effect of moisture control in pile-type composting of dairy manure by adding wheat straw on greenhouse gas emission. International Congress Series, 1293, 311-314.

[16] Thompson, A. G., Wagner-Riddle, C. \& Fleming, R. 2004. Emissions of $\mathrm{N}_{2} \mathrm{O}$ and $\mathrm{CH}_{4}$ during the Composting of Liquid Swine Manure. Environmental Monitoring and Assessment, 91, 87-104.

[17] Xu, S., Hao, X., Stanford, K., McAllister, T., Larney, F. \& Wang, J. 2007. Greenhouse gas emissions during co-composting of cattle mortalities with manure. Nutrient Cycling in Agroecosystems, 78, 177187. 